\title{
Ingredient branding to build a luxury cluster-the case of Calais lace $®$
}

\begin{abstract}
Suppliers of luxury fashion fabrics in France have historically been working in fierce competitive ways. Lace-makers are no exception. Created in 1952, the Lace of Calais ${ }^{\circledR}$ label can be used by those using Leavers machines. However, it is currently dying, being unequally used by the various lace-makers, retailers and fashion companies. Action Research was selected to help reposition it, endowing it with a new identity that would enhance manufacturers' own brand equity. In short, the aim was to craft an ingredient branding strategy. We relied upon various data collection and analysis methods: interviews with all types stakeholders (open-coding and axial coding); structural semiotic analysis of the label; non-participant observation and non-directed interviews with all lace-makers (lexical analysis); market analysis.
\end{abstract}

We also aimed at enhancing knowledge on: (1) information processes in a bi-located cluster with internal "fights"; (2) various points at stake when clustering happens inbetween non-aligned partners; (3) ingredient collective-branding.

Keywords: ingredient branding, luxury manufacturing, industrial cluster
Volume 2 Issue 3 - 2017

\author{
Anne-Flore Maman Larraufie \\ Director of Sémio Consult, ESSEC Business School, France
}

Correspondence: Anne-Flore Maman Larraufie, Director of Sémio Consult, ESSEC Business School, 45 rue Brillat Savarin, 75013 Paris, France, Tel 330603010213 ,

Email maman@essec.edu

Received: May 24, 2017 | Published: July 19, 2017

\section{Introduction}

In vein with current strategic development trends, Calais and Caudry lace makers have initiated a shift in their strategic orientation. Instead of a market-based approach, they have started a resourcebased one, with resources and competencies as the foundations of their strategies. This is consistent with economic times (esp. the lace crisis, see history hereafter) and manufacturing evolutions with the race towards innovation. ${ }^{1}$ SMEs usually try to combine individual and collective resource-based strategies. They work on their brand equity, and simultaneously engage in collective branding strategies, such as in the case of Calais Lace in 1952.

Since then, the economic environment has been more and more encouraging concerning such initiatives. Two recent developments in French economic strategy are worth notifying, to better understand the current framework in which our action research took place: the move towards the so-called 'Poles of Competitive', and the 'IGP manufactures' ongoing legislation. First, the "Poles of Competitive" (Competitive Clusters) was settled in 2004, to foster innovation capacity and raise economic growth and job employment in promising markets (DATAR, 2004). Such cluster gathers on wellidentified companies, laboratories and training/education centres on a given economic 'topic'. National and local official entities are also involved in them. On top of that, the lobbying of some wellknown manufacturers issued in a law-project (2014) on manufactured GPIs, for instance for Marseille Soap, Laguiole Knifes or such. Lace of Calais ${ }^{\circledR}$ would be eligible to apply. It is in this context that the present research has been undertaken, with the dual managerial objective of revising the potential of the Lace of Calais ${ }^{\circledR}$ qualitylabel and of repositioning it. Besides, the present action research aimed at enhancing knowledge on several key topics: understanding better the information processes in a cluster that is bi-located, and with internal "fights"; and grasping the various points that are at stake when clustering happens in-between non-aligned partners.
More specifically, we wanted to uncover how decisions happened, and stimulate new ways for decision-making optimization. A last objective was to reflect upon ingredient collective-branding strategic developments, as most literature on branding concerns individual brands and not collective ones Leek \& Christodoulides. ${ }^{2}$

\section{Ingredient branding and in branding}

Lace is a fabric used as an ingredient by several actors, from fashion brands to interiors' architects, including fine lingerie or shoemakers. Therefore, if French lace makers decide to develop a real branding strategy for their collective label Lace of Calais, they need to understand the stakes at entering an ingredient branding strategy, to use the best arguments to convince their clients to use the logo of the label. They should aim at building a brand image, increasing the brand's value to their clients and leading to brand loyalty Rooney. ${ }^{3}$ Doing it the right way is key, as ingredient, branding is not suited for all companies or brands Abbo. ${ }^{4}$ It entails opportunities Norris, ${ }^{5}$ and risks Boad. ${ }^{6}$

The Lace of Calais ${ }^{\circledR}$ collective brand is a quality label, ensuring distinctive features of the product, from technical ones to emotional ones, including image ones (through the Made in France). Usually, host brands in an ingredient branding strategy use ingredient branding to improve their brand equity: their associations, the cognitive dimension of attitude toward the brand, their overall evaluation (affective dimension), and their perceived quality Bengtsson \& Servais. ${ }^{7}$ Besides, careful management of their suppliers is a strategic competitive advantage for textile manufacturers in General Su J et al. ${ }^{8}$ The Lace of Calais ${ }^{\circledR}$ brand will therefore have an impact on their clients' brand and needs to build its branding strategy accordingly. This will enable host brands to exploit its brand equity and associations in a positive way Abbo. ${ }^{4}$ Such strategy would lead to attractiveness for logo display of the Lace of Calais ${ }^{\circledR}$ label by its users, whatever the positioning, but especially in the case of moderate-quality host 
brands. This assumption comes for the fact that consumers evaluate a moderate quality host brand more favourably when a high-quality branded ingredient is used, while is its only slightly true for highquality host brands McCarthy \& Norris. ${ }^{9}$

However, an ingredient branding strategy does not only focus on clients. It should also target final consumers: if they understand and know the functions, features and benefits of the ingredient, they will pay more attention at its offering Desai \& Keller. ${ }^{10}$ In the best case, i.e. when a unique product offering exists, loyalty and profitable consumer relationships are built. Therefore, the ingredient branding strategy overcomes the burdens of traditional B2B brand strategies. ${ }^{11}$ In the case of clothes, research has found that final users assess the quality of a garment based on the fabric Hines \& $\mathrm{O} \mathrm{Neal}^{12}$ so ingredientbranding should be an attractive strategy for manufacturers from this perspective as well.

Ingredient branding strategies are rare in luxury, and most often considered from the host brand's perspective. However, "the value of branding has also been recognized by suppliers who produce ingredients or components that are incorporated into final products" McCarthy \& Norris ${ }^{9}$ Norris. $^{5}$ In some cases (most of the times in electronics and textile), supplier-initiated ingredient branding occurs. This is the aim of the lace makers from Calais and Caudry (see below for the geographical history of the production): they have started initiating a promotion of Calais Lace, which is a part of the end product, to the final user to create brand awareness, back in 1991 with the creation of the first label. They hoped that such investment in brad awareness would result into consumers requesting Calais lace, 'pulling' the ingredient brand from the manufacturer. Such branding effort, initiated by suppliers, is called as In Branding Pfoertsch et al. ${ }^{11}$ and put into a model as shown in Figure 1.

\section{B2B2C}

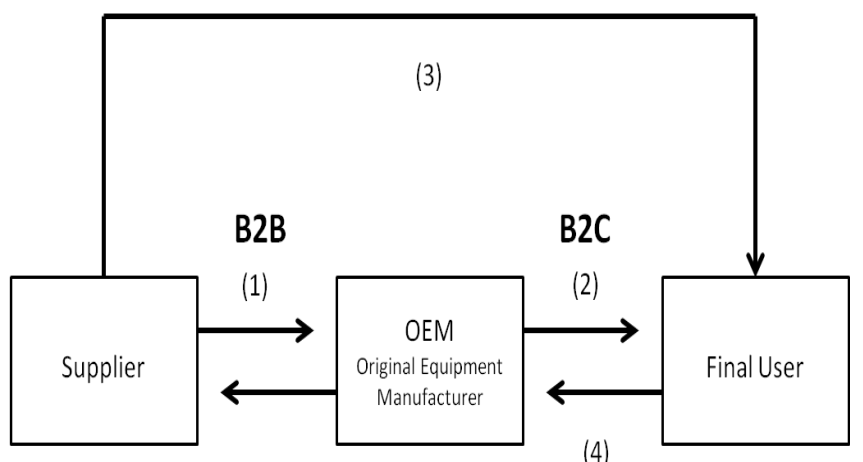

Figure I In Branding Principle.

Usually, two separate stages of customer relationship happen in a B2B2C context: supplier with OEM (Original Equipment Manufacturer), and OEM with final user. In their model Pfoertsch et al. ${ }^{11}$ explain that the two stages are interconnected: step 2 follows step 1, and step 3 occurs simultaneously. Here, the supplier directly addresses the final user that his ingredient is part of the final product offering, which makes him select this product over competitive offerings. Thus, step 4 happens, with final users pulling the product because they desire the particular ingredient component.

In Branding is particularly suitable when the number of OEMs is high and number of suppliers is low, and/or when the complexity of components in relation to final product is high while the importance for functionality of final product is low. This is particularly the case for Calais lace, so In Branding appears a relevant strategy for our Action Research mission. As any branding strategy, In Branding is not automatic and takes time (from 5 to 10years). It completes in four steps Pfoertsch et al. ${ }^{11}$ raising of credit (exploitations of reputation), break-through and market proof, repayment of credit (synergy), and fiesco-effect ("The ingredient brand is present everywhere and could not be used as a differentiator") in Table 1.

Table I The Life Cycle of In Branding."

\begin{tabular}{lll}
\hline S. No. & Steps & Description \\
\hline Raising of credit, & $\begin{array}{l}\text { Unknown ingredient brand } \\
\text { exploitations of } \\
\text { reputation }\end{array}$ & $\begin{array}{l}\text { befit from the association } \\
\text { with well-known product } \\
\text { brands }\end{array}$ \\
& $\begin{array}{l}\text { Break-through and } \\
\text { market proof }\end{array}$ & $\begin{array}{l}\text { The Unknown ingredient } \\
\text { brand becomes known and } \\
\text { famous on its own }\end{array}$ \\
& $\begin{array}{l}\text { Repayment of credit, } \\
\text { synergy }\end{array}$ & $\begin{array}{l}\text { Known ingredient brand is } \\
\text { helping its supporter, as well } \\
\text { as benefiting itself }\end{array}$ \\
& & $\begin{array}{l}\text { The ingredient brand is } \\
\text { present everywhere and } \\
\text { could not be used as a } \\
\text { differentiator. The lack of } \\
\text { differentiation increases the } \\
\text { chance for the price war } \\
\text { amongst former supporters }\end{array}$ \\
&
\end{tabular}

\section{Industrial clusters/districts}

Given the economic and technological context, combining resources would be the winning strategy for geographical territories Veltz. ${ }^{13}$ This is the rationale between industrial clusters. The theory on clusters has been described by Porter (1990). According to him, four elements enable the cluster to be competitive:

a. The cluster has to encourage some kind of emulation among the different companies that compose it;

b. Human resources of these companies should display solid scientific and technical competencies with infrastructures allowing exchanges in-between such resources;

c. Local market need to be qualitative to favour innovation and performance;

d. Clusters need to be surrounded by a thick network of suppliers and other industries to multiply interrelations Porter. ${ }^{14}$

In Italy, the concept of clustering is part of the industrial reality of the country. The so-called distretti are geographically limited areas in which SMEs of the same industrial branch concentrate, relying upon traditional or industrial history, i.e. some local know-how. Cooperation relies upon the sharing of a same business activity, without turning off competitiveness in-between members Sabel \& Piore. ${ }^{15}$

The French move towards the Competitive Clusters is a testimony of official willingness to set up business networks. It should in the end influence positively the geographical area's attractiveness as well. The most important difficulty is the nature of the companies that 
compose them, often SMEs, with heavy competitiveness in-between themselves. Therefore, it is hard to identify an acknowledged leader, in capacity to federate the cluster Bouabdallah \& Tholoniat. ${ }^{16}$ Similarly, as no real history of collaboration exists between French SMEs and education networks, it is hard to create from scratch such. These are two aspects further developed. However, one positive point for it: the various factors involved in the clustering process of the Calais lace whole share a common lace culture, a prerequisite to create territorial economic intelligence Pecqueur \& Zimmerman. ${ }^{17}$

\section{Geographically linked collective brands}

Most Western countries have set up legislative frameworks to valorise a product's origin. They are very popular in Europe, ${ }^{18}$ usually registered as geographical indications for agricultural products, as they have earned some producers large premiums Babcock \& Clemens ${ }^{19}$ and encourage adding value locally, which can result in a positive impact on the rural economy Clemens, ${ }^{20}$ Hayes. ${ }^{21}$ They act as guarantees of origin and inherent quality of the product, provide traceability, and ultimately tell the 'story' of the brand. They have thus become real tools for economical politics. With current extension of such GPIs to manufactured products, it is worth considering the Lace of Calais ${ }^{\circledR}$ collective brand as a relevant candidate. Actually, it holds the background components for certification systems, be they European or American, namely a history and raw materials, both related to the geographical origin Babcock et al. ${ }^{18}$ In the case of lace, the raw material is not the fabric, but the machines and drawings, along with the know-how only found in the area. However, in a repositioning strategy, one should keep in mind the importance of choosing the brand name not for oneself, but with target markets in mind, as any commercial brand Keller. ${ }^{22}$

GPIs hold advantages for many actors, from territories to manufacturers, including collectivities and consumers Scudeller. ${ }^{23}$ They do not only help defend a product name against imitations and counterfeits, but ensure greater product visibility, more information to consumers (enlarging their choice panel), and ultimately some added-value to manufacturers/producers Scudeller. ${ }^{23}$ Therefore, their name is collectively selected by the producers, an important part of our action research. All these strategic interests do not cancel more pragmatic economical ones, linked to the IP nature of geographically protected brands. As such, they hold rights to collect income from the differential effect they create in consumers' minds, leading to premium pricing and inelastic demand. This follows price setting in a monopolistic competition Chamberlin. ${ }^{24}$

\section{Lace of calais project-background}

It is at the beginning of the 19th Century that English people from Nottingham build the first mechanic tulle loom inspired from the stocking loom/frame invented in 1589 s by Sir William Lee. Trade of goods had been re-authorized since the Restoration (following Napoleon's blockade), but English lawmakers forbade the exportation of any of these new looms. Punishment was death sentence. However, the geographical proximity of Calais combined with opportunities of making profit acted as stimulators for some English workers to disobey the law. The first loom reached Calais in 1817, dismantled and carried from various coastal points by smugglers. Placide Gabet installed the first tulle loom in Caudry in 1825. Adaptation of the Jacquard system to the tulle loom and the arrival of steam power between 1835 and 1840 resulted in machine-made lace production on an industrial scale.
The number of looms kept increasing until the end of the 19th century, reaching 2000 machines in Calais. Production capacity was at its climax at the beginning of the 20th century, thanks to the technical possibilities of the Leavers lace looms combined with sketchers' creativity. Calais became the world capital for lace with more than 40,000 people working in the industry. Caudry had a later start. It then grew at a very fast pace as well.

Now, with more than 600 Leavers looms ( $80 \%$ of the world's), both cities enjoy a worldwide reputation for lace making. Calais is more specifically known for manufacturing lace fitted for fine lingerie, and the second for garments (ready-to-wear and haute-couture). Calais and Caudry have cultivated their originality from the birth of lace making industry, with respect to their respective history, markets, industrial and working culture. For instance, they both have their 'Chambre Syndicale' (representative body of CEAs) that joins separately the FFDB (French Federation of Lace and Embroidery). During quite a long time, the economical weight of Calais was more important than Caudry's one. However, since a couple of years it has changed hands, following the general decrease in Leavers lace-usage in the lingerie market due to competition from Asia (lower prices). Today, Caudry holds more companies, workers and has an overall greater turnover than Calais. This means altered relationships in-between both places.

Besides, owing to the sector economic difficulties, new bounds have emerged in-between some companies within a given place showing again a different organizational structure than previously. Mergers and acquisitions have happened, especially to integrate complementary activities to lacemaking, such as dying. Such situation implies new dialogue necessities, which is not that easy to consider given the historical internal wars within and in-between both places. The destiny of both places is intertwined and this reality cannot be ignored.

\section{The label 'lace of calais $\circledR$ '}

In 1958, lace makers from Calais decided to register the label, as a distinctive sign to differentiate Leavers Lace (made in Leavers looms) from knitted lace (made on Rachel looms), a cheaper and less qualitative lace some of them were starting to manufacture. Lace of Calais ${ }^{\circledR}$ is a protected trademark, reserved exclusively for lace manufactured in Calais and Caudry, 100\% made in France, on Leavers looms, by a unique method of knotting warp and weft dating back to the early 19th century.

The actors are thus (1) the FFDB, (2) five companies in Calais standing for around 20million Euros in turnover for Leavers lace (Noyon Lace with 225 employees, Desseilles Laces with 84 employees, Codentel with 56 employees, Cosetex with 6 employees), and (2) seven companies in Caudry standing for around 50million Euros in turnover for Leavers lace (Sophie Hallette with 166 employees, Solstiss (gathering four companies) with 138 employees, Jean Bracq with 42 employees, Beauvillain Davoine with 31 employees, Laces Méry with 47 employees, Laces MC with 10 employees, Laces Laude with 22 employees). Around $75 \%$ of total production is for exportation.

\section{Materials and methods}

We selected Action Research as the relevant methodology to reach the objectives (Stringer, 1996). It would enable us to take advantage of the consulting job we were engaged in, as a fertile ground for academic developments. Special attention was paid at not confusing 
both activities, given that consulting is work done for practitioners, while action research engages more systematically with knowledge creation Bradbury Huang. ${ }^{25}$

Definitions of action research vary, depending upon the research context and researcher's discipline. The focus might be on 'research' Cherns ${ }^{26}$ or more on action Rapoport. ${ }^{27}$ In the present case, it was more action-oriented, aiming at contributing "both to the practical concerns of people in an immediate problematic situation and to the goals of social science by joint collaboration with a mutually acceptable ethical framework".

The research process selected in the present study follows Wilson's guidelines (2000). Summarized in Figure 2, it is a loop:

i. Problem identification: the problem may be identified in-house or by the researcher. It might be of diverse nature, but most of the time includes some organizational issues.

ii. Negotiation to establish terms of entry and program of research: the conditions under which the research is permitted must be settled and jot down in an agreement.

iii. Data collection: all standard methods of data collection may be used, be they quantitative or qualitative, and should they deal with primary or secondary data.

iv. Feedback to participants and management: an essential element in action research, which is its main distinctive feature from other types of research. It may be done by written report, by oral presentation at meetings, or both.

v. Discussion on results of feedback, evolution of ideas for action: the logical follow-up to the feedback step. Some points need to be validated, other challenged and ideas for action plans might thus be generated.

vi. Preparation of action plans: the operational translation of the ideas discussed at stage 5, complemented by the researcher's recommendations based on his expertise. Action plans are meaningful only if relevant and convincing for the organization under study, so the various implications, resources and time-scope should be carefully thought and considered in the proposal.

vii. Implementation of action plans and monitoring: the action plans are put into effect, with the researcher's monitoring and control.

viii. Problem re-definition, etc. as necessary: the researcher may withdraw, leaving the organization to pursue the research process alone, may remain as an advisor for technical assistance, or may be fully involved. This usually depends upon the needs and wishes of the organization, along with budget.

\section{Lace of calais project-problem identification}

The problem was identified in-house, more specifically by the labelowner, i.e. the FFDB more than one year before starting the project. This time-lapse is revealing the complexity of the organization and approach to the problematic, as explained later, and has several facets:

Competition: French Leavers lace, especially the one dedicated to the lingerie market, face nowadays more and more competition by knitted and lace and by foreign manufacturing. Knitted lace is manufactured all over the world (including in Calais). Its cheapest version comes from China, and imitates better and betters the visual appearance of Leavers lace. Delays of production are also shorter.
Foreign manufacturers holding Leavers loom also produce Leavers Lace (mainly the Japanese Sakae with looms installed in China and Thailand). They hold lower manufacturing costs and made effective progress in terms of quality of the fabric.

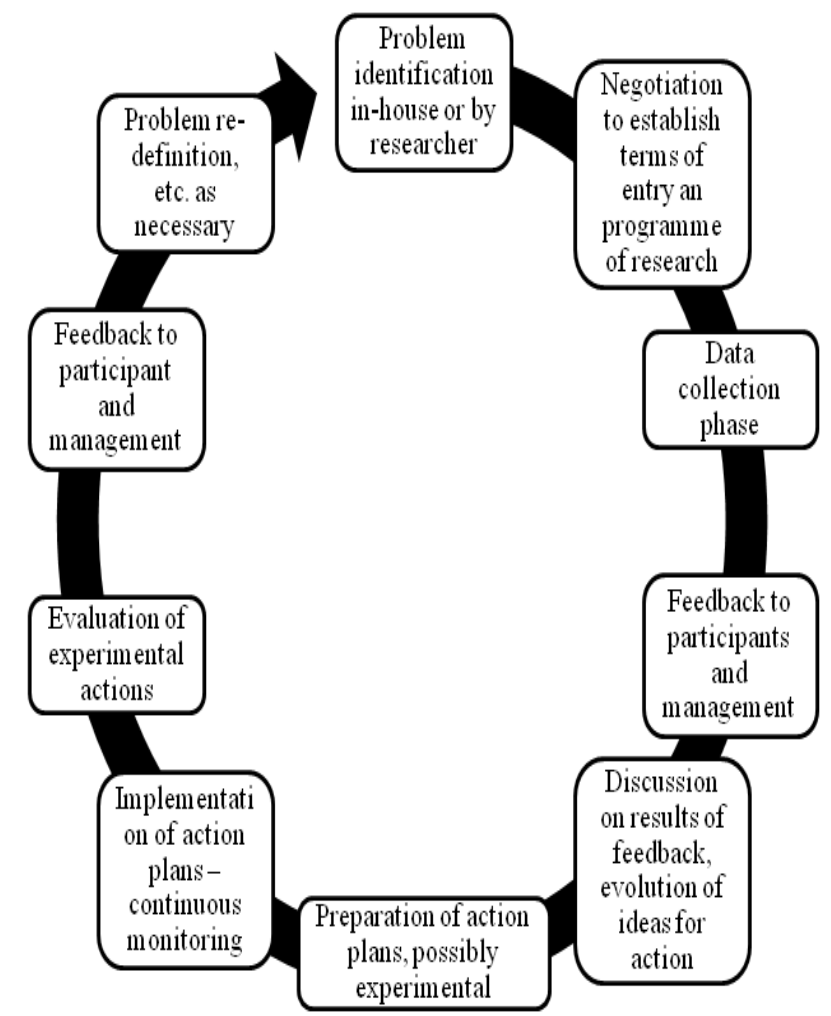

Figure 2 The cyclical Process of Action Research (Wilson 2000).

Misuse of the label: Not all manufacturers in capacity of using the label do it. Some do not display the logo on their commercial labels, website etc. Most companies from Caudry prefer developing their own corporate brand image, especially when it already holds some reputation. Besides, they do not recognize themselves in the collective brand, as the name includes only Calais. Thus, most of the time the brand has been used by lace-makers focusing on the lingerie market, from Calais. This has contributed to spread the general belief that there is a brand association with lingerie, implying a degrading image for garment-makers. Similarly, lingerie brands tend to use more the commercial label than garment makers, and mass-retailers do it more than luxury retailers do as well.

Risk of confusion: To deal with Asian competition, some lacemakers from Calais have acquired in the 60s Rachel looms in addition to their Leavers looms. Today, Noyon Lace and Desseilles do not only produce Leavers lace, but also some knitted lace with jacquartronic and textronic looms. Therefore, they can use the collective brand only on some part of their overall production of lace. This raises questions regarding (i) a potential confusion between Lace of Calais ${ }^{\circledR}$ and lace made in Calais and (ii) how to increase the status of Lace of Calais ${ }^{\circledR}$ without damaging or diluting other types of lace that are made in Calais. Therefore, there is a need to increase the status of the collective brand to play in a collective spirit and join forces to deal with Asian competition; convince all lace-makers that the collective brand can be a plus to their own corporate brand that they should advocate; and attract attention of lingerie/garment-makers, and retailers regarding 
the added-value of Leavers lace and the opportunity behind using the collective brand as a sales argument. In some words, the objective is to develop a real ingredient-branding strategy, considering the organizational issues and capitalizing on the current positive features of the Lace of Calais ${ }^{\circledR}$ brand image.

\section{Lace of calais project-negotiation phase}

The entry phase was easy in our case, as the FFBD came to us to solve the problem. It had been one year and a half we kept exchanging ideas and concerns on the Lace of Calais ${ }^{\circledR}$ label. Therefore, we were sure to negotiate something mutually beneficial for us and for the client Dick. ${ }^{28}$ We came to an agreement in which we oversaw the mission, with $100 \%$ access to any lace maker and primary data (including the archives), with regular reporting to the FFDB. The General Secretary would also join the interviews and focus groups with lace makers, without interrupting (as an external observer). She would take down notes for further debate. We also agreed on copyright matters, the methodology being ours, and the results theirs. We could report on final decisions and non-confidential points related to the issue, but confidential points should be kept so.

Practically speaking, this means that we can publicly share only results and action plans, esp. in terms of written report. This explains the shape of the successive parts of the present paper.

\section{Data collection}

Several methods were used to collect data, so that we could triangulate findings and thus increase rigor of our research findings Jick. ${ }^{29}$ Besides, we had to get a holistic perspective on the issue. As already explained, the present study involves many actors: the FFDB, the lace-makers, final consumers, manufacturers (lingerie and garments), and retailers.

First, we had to deal with two types of data: primary and secondary. We started with secondary data to uncover the research background (history of Calais Lace and lace-makers, etc.) and kept collecting some while collecting primary data as well, on an ad-hoc basis.

Secondary sources: We collected data from the FFDB's and lacemakers archives, in the press, in books and in video documentaries (including news on TV). As a first step, the objective was to understand the historical background of the collective brand, its origin (why it had been created), and the perspectives of people from then. Besides, the current context was of importance to provide recommendations regarding how to build some collective spirit around the brand, so as a second step we collected data from the general press to understand the various inter-lacemakers issues, when not 'wars'. That was key to understand the spirit in which the research was to be conducted, and be well prepared to respect sensibilities and avoid annoying situation owing to lack of knowledge. Besides, there were high probabilities that lacemakers would not fully express themselves on such sensitive issues, especially owing to the FFDB's secretary presence during all interviews and meetings, as part of the negotiation deal.

Lastly, we needed to put back into context the research within its sector of activity, i.e. fashion. We thus collected data from the press, magazines, blogs, social networks and observing the catwalks, to understand the current and forecasted trends in lace-usage, for both lingerie and garments. To the query of the lace makers, special attention was given at Occidental, Chinese and Middle East markets. For the two last ones, two research assistants were recruited, one native in Chinese and the other one in Arabic. They were not aware of the research purpose, but were only in charge of conducting traditional trend analysis. This way we made sure to get objective data. For all secondary sources, special attention was paid at their relevance and credibility, which could be assessed from their origin of publication.

Primary sources: We used several qualitative and quantitative methods to collect primary data, from January 2014 to June 2014.

A. Observation of the current logo

B. Non-participant observation in lace plants, trade shows and exhibits

C. Semi-directed interviews with lace-makers, including metaphor-elicitation. The objective was to understand their personal vision of the collective brand, how it would be matching their individual brand history and strategy, and grasp their emotional attitude towards the collective brand. The metaphor-elicitation was used to get a broader picture of the collective brand personality they had in mind

D. 15 Narratives with lace-makers, to let them tell their relationship with lace. It was fundamental to let them freely share the familial -nature of their respective companies.

E. Ad-hoc on-site interviews with blue-collar workers in the factories, and with designers/marketers/distributors on the trade shows

F. Questionnaires with final consumers to understand their relationship with lace and assess the degree of knowledge about Calais lace. Besides, we wanted to assess the understanding they had of the current logo. Questionnaires were administered online in two languages (French and English) and we got a valid sample of 338 respondents for our consumers' questionnaire, including 156 French people and 182 foreigners

G. Directed interviews with designers and marketers (63 clients: 40 designers and 23 marketers/retailers including future ones) to understand their relationship with Calais Lace, how much brand knowledge they have, and what brand image they hold. Knowledge related to the brand and to the logo was under interest.

Samples: We interviewed 15 lace makers for narratives and 63 clients (40 designers and 23 marketers/retailers including future ones). We got a valid sample of 338 respondents for our consumers' questionnaire, including 156 French people and 182 foreigners are see sample's characteristics in Table 2.

\section{Data analysis}

Traditional methods were used to analyse data, selected on their relevance to analyse data depending on its nature, combined with the research objectives in mind. More specifically, we used the following methods:

a. Content analysis following the method of categorization of the data Strauss \& Corbin..$^{30}$ It was used to analyse secondary data, open answers to the consumers' answers, verbatims from interviews with designers/marketers/retailers, ad-hoc interviews with workers.

b. Content and discourse analysis Fairclough ${ }^{31}$ to analyse lace makers' narratives.

c. Visual semiotics (plastic, figurative and Gestalt) to analyse the logo. 
d. Basic statistics to analyse the quantitative data in consumers questionnaires.

Table 2 Sample of respondents

\begin{tabular}{llll}
\hline \multirow{3}{*}{ Gender } & Men & 47 & $14 \%$ \\
& Women & 291 & $86 \%$ \\
& Less than 15 & 0 & $0 \%$ \\
& $15-20$ & 21 & $6 \%$ \\
& $20-30$ & 138 & $41 \%$ \\
Age & $30-40$ & 93 & $28 \%$ \\
& $40-50$ & 42 & $12 \%$ \\
& $50-60$ & 24 & $7 \%$ \\
& $60-70$ & 12 & $4 \%$ \\
& More than 70 & 8 & $2 \%$ \\
\hline
\end{tabular}

\section{Results and discussion}

\section{Surrounding noise}

Calais lace is a subject of concern for the press, be it local, national or international. However, the correct name of Lace of Calais ${ }^{\circledR}$ is not always used, as some journalists quote it as Lace of Caudry or Lace Leavers.

We analysed the noise by press type (local, vs. national, vs. international), and then by concepts they deal with. In general, the lexicography of war is present for both Calais and Caudry places. However, when speaking about Calais, clippings focus on lace makers and their factories, while they focus on the end-users/clients/ products when speaking about Caudry. Content analysis led to the following observations: Lace of Calais ${ }^{\circledR}$ is presented as a defensive tool; the product is presented under its technical and utilitarian dimensions, never under its hedonic or utopic one; Caudry is subject to museumization; and Houses of lace making do matter.

\section{How is lace perceived by 2 Ist century consumers?}

For all respondents, lace is synonymous with feminine, delicacy, lingerie, romantic, elegance, sensuous, chic and beauty. For men only (French and Non-French), it is synonymous with sexy. For nonFrench respondents (Men and Women), lace is synonymous with luxury, Calais, and fashion. For foreign women only it is synonymous with wedding, while for their male counterparts it is synonymous with out fashioned. Lastly French people associate it with know-how, and French men (not women) with glamorous. On the contrary, three adjectives are not at all synonymous with lace: vintage, modernity and heritage.

\section{Brand equity-some insights}

Brand equity is composed of brand knowledge/awareness and of brand image Keller. ${ }^{22}$ Brand knowledge has been assessed both in its recall and recognition components.

Our confidentiality agreement does not allow us to explain how we came to the findings; however, we can share here the final observations and conclusions which will support the plan of action later.

The framework used to conduct the Brand Audit used the following identity-box see in Table 3. It is rational behind any brandbuilding project to consider that any time a consumer/prospect/ stakeholder is in contact with the brand, he is actually shaping the brand image through an associative network Keller. ${ }^{22}$ Therefore, we looked carefully at Traditional Communication Activities, the Signature System, Brand Spaces, Products, Business Culture (with the complexity of the cluster-nature of the 'business' under study), and Consumers' Behaviours. As we deal with a collective ingredient brand, one should keep in mind that consumers of the collective brand are lace-makers themselves in a first place.

Table 3 The Brand-Identity Box

Brand identity elements

\begin{tabular}{|c|c|c|c|c|c|}
\hline $\begin{array}{l}\text { Traditional } \\
\text { communication } \\
\text { activities }\end{array}$ & Signature system & $\begin{array}{l}\text { Outlets offices } \\
\text { plants }\end{array}$ & Products & Corporate behavior & $\begin{array}{l}\text { Consumers' } \\
\text { behavior }\end{array}$ \\
\hline $\begin{array}{l}\text { Advertising } \\
\text { PR } \\
\text { Events } \\
\text { Internet }\end{array}$ & $\begin{array}{l}\text { Logo Signboards } \\
\text { Labels Packaging } \\
\text { Header }\end{array}$ & $\begin{array}{l}\text { Places Internet } \\
\text { Architecture Light } \\
\text { Decoration } \\
\text { Windows } \\
\text { Selling style } \\
\text { Merchandising } \\
\text { Uniforms } \\
\text { Code of Conduct }\end{array}$ & $\begin{array}{l}\text { Number Categories } \\
\text { Shapes Materials } \\
\text { Style Performance } \\
\text { Lifetime } \\
\text { Price Availability }\end{array}$ & $\begin{array}{l}\text { Social, human \& } \\
\text { environmental activities } \\
\text { Company's \& } \\
\text { Employees' behaviors } \\
\text { Behavior of other } \\
\text { entities (suppliers, } \\
\text { foundation). Ethical } \\
\text { charter }\end{array}$ & $\begin{array}{l}\text { Who are } \\
\text { they? } \\
\text { What do they } \\
\text { do? }\end{array}$ \\
\hline
\end{tabular}

Main findings were:

i. Traditional communication activities stress-out the physical characteristics of the label.

ii. It is not clear on the brand's website whether the audience is composed of connoisseurs or of novices.

iii. The logo conveys the following ideas (in brackets the potential negative extensions): source of creativity, fertility, symbol of royalty (Excess, Proudness, Ubris); energy, luxus (Excess, disorder); discontinuity, exuberance; free-reading of the icon with lots of potential interpretations.

iv. Slogans change according to context

v. The first ambassadors of the label are lace-makers themselves

vi. Unequal usage of the sticker by lace-makers, with different discourses

vii. Unequal usage of the sticker by manufacturers and retailers, with a focus on final product and on the quality of the fabric.

As one can see, emotions are quasi-absent from the identitybuilding project of the collective brand. If I confront this with current trends in consumption, it does not seem quite aligned, especially in the luxury area Dubois \& Paternault. ${ }^{32}$ 


\section{Organizational issues}

Organizational issues happened at various phases of the action research process. Some were inherent to the mission conduct, such as setting up meetings, while others were identified by the researcher as blocking elements for the good health of the label. Finally, some were more individual-related, especially when it came to actions to be done by the FFDB. Without being too expensive on this final point, it appeared that the Secretary, who has been involved in her task for more than 10 years, has gone through conflicting moments with lacemakers in the past. This, combined with her quite emotional nature, refrained her from being proactive and made her somewhat dependent on lace makers' good willingness.

Setting-up meetings was a challenge and worth a word, as a testimony of the spirit in which the collective brand was to blossom. Calais and Caudry being two competitive cities, it was out of the question to mix all of them in all meetings. Therefore, some separate meetings took place in both cities. In Calais, the City International of the Lace was used, but in Caudry not such space would exist. No one lace-maker would agree going for a meeting at another lacemaker's premise. Therefore, meetings were organized in Cambrai, in the MEDEF's premises. Similarly, when needing to get both places around the table, we had to find a 'neutral' place, which happened to be Arras. These meeting places issues may sound not that important. However, if all lace makers want to join in a common strategy for the Lace of Calais ${ }^{\circledR}$, such organizational challenges slow down the process (travel distances are not nil, implying the absence of some of them, each time).

The last organizational problem we identified is in the brand management of the label. The IP holder of the brand is the FDDB. As such, it remains the 'seller' of stickers/merchandising items etc. to lace makers who then propose then to retailers or manufacturers. Brands and retailers cannot directly order stickers, or send a communication request, to the FFDB. Lace makers are a compulsory intermediary step. This may appear 'old-fashioned' style of managing a brand, and time-costing for marketers in such entities, thus decreasing the attractiveness of the label to them.

\section{The plan of action}

Towards a new brand identity: After a face-to-face presentation of the brand audit, in the format of two workshops (one in Calais, the other one in Cambrai), we compiled the brand identity project to propose a common middle ground which would reconcile the perspectives of both places. We ended-up with a final identity-definition for the collective brand, through the following aspects: Root Strengths, Competitive Environment, Target, Insight, Benefits, Discriminator, Values-Beliefs and Personality, Reasons to believe, Essence.

Then we also defined the new brand personality to help give direction for future marketing and communication activities. The new DNA was defined using the GATTACA framework that presents 7 components (bases) to brand identity: Guarantee (promise), Authenticity, Temporality (history), Technicality (competence, knowhow), Actors, Codes, and Action as shown in Figure 3.

Lace-makers reached an agreement on the fact that the icon had to be revised, and that the brand name should be updated, including both places names. This is a huge step in their collective thinking process, as it has been ten years since they had not agreed on either one.

The researcher thus wrote a creative brief and summary of the brand identity project, to submit to a pool of designers for competition. Eight designers were selected, either belonging to agencies, or freelancers. The usual designer used by the FFDB belonged to the sample. Five of them presented an initial project for the new logo. Each proposal has then been submitted for an online vote (with no knowledge of what the others would vote), after a debriefing of the researcher regarding each proposal. Results happened to be quite homogeneous. This could have been different if the choice had happened during a meeting session, from the words of the FFDB's Secretary.

\section{Brand DNA: Bases}

- G: Guarantee (promise)
- A: Authenticity
- T: Temporality (history)
- T: Technicality (competence-know-how)
- A: Actors
- C: Codes
- A: Action

Figure 3 The GATTACA Framework.

The choice of the graphic designer for the new visual identity took 4 months. We did not expect this, as creative briefs were handled for competition at mid-July 2014. We believe this is symptomatic of the expectancy behaviour of lace-makers, and of their lack of commitment in intangible assets. The usual FFDB's designer has not been selected, and our input has been highly required during the rework of the whole logotype.

Further recommendations: Besides the new brand identity project, several additional recommendations were provided. All derive from the core audit conclusions or side-ones:

a. Construct a label database (sorted and indexed archives and photo database of reference)

b. Give the label some credibility and visibility through a complete reshape of the label website

c. Enlarge the communication potential of the label (avoid double-validation process, see before)

d. Enhance knowledge of the label and of the product, with two pedagogical kits (one for designers, one for business people)

e. Educate sellers (serious game)

f. Strengthen the dream formula associated with the label: brand content, storytelling and product placement

g. Build some relationship with final users through a lace-authentication function on the label website 
h. Rethink human resources dedicated to the management of the label

\section{Conclusion}

This action research project took three times the expected lapse of time. This reflects how complex and time-costing building a collective brand with competitive members can be. The practical clients' objectives were met, one by one.

Besides the managerial outcomes, this project aimed at understanding better information processes in a cluster that is bilocated, and with internal "fights"; grasping the various points that are at stake when clustering happens in-between non-aligned partners, esp. in terms of decision-making processes; and at reflecting upon ingredient collective-branding strategic developments.

\section{Understanding information processes}

As stated earlier on in this paper, processes were long and complex. They happened in a format depicted in (Figure 3) (Figure 4).

For historical reasons, information is centralized within the hands of the FFDB's Secretary. She handles fluxes of information and most of the times this implies longer time-lapses. More specifically, lacemakers hardly ever communicate in a unite voice: this never happens for both places together, and might happen on occasional basis for single-places. Most of the times they communicate on a one-to-one basis with the FFDB, which contacts them on a one-to-one basis as well. When harmonization of the voices is needed, meetings are organized.

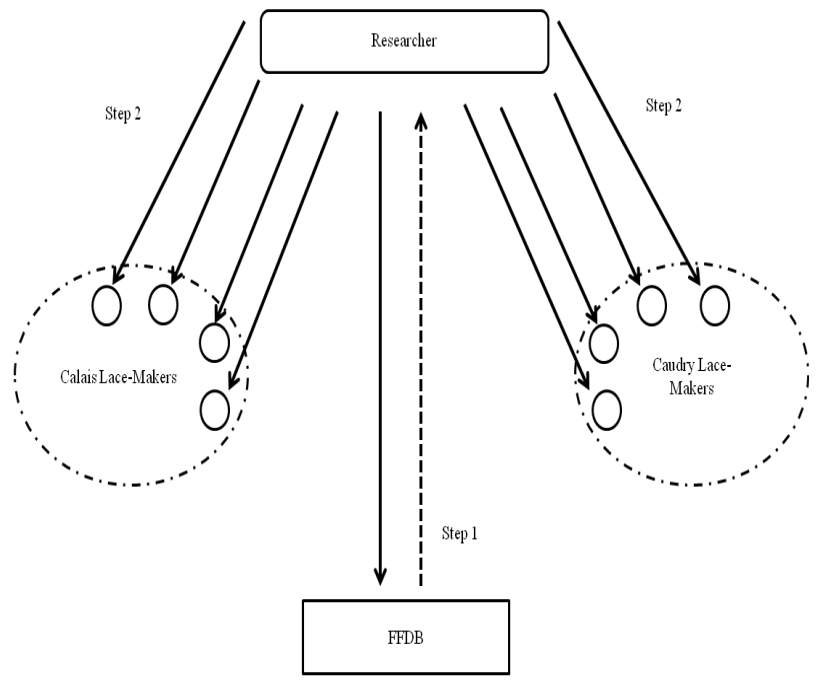

$\begin{array}{rr}\longleftrightarrow & \text { Informations } \\ \text { Feedback }\end{array}$

Figure 4 Communication Process Option I.

One the researcher needed to contact lace-makers, two information processes could happen:

Option 1: Contact the FFDB and validate the fact that he would contact lace-makers on a one-to-one basis in Figure 4,

Option 2: Contact the FFDB that would forward the information/ query on a one-to-one basis, then collect individual responses and forward them to the Researcher in Figure 5.

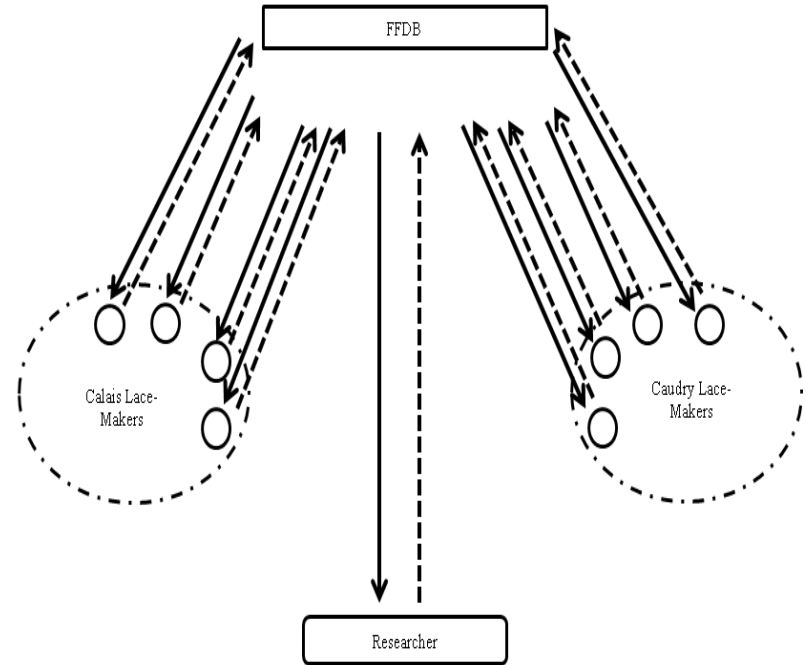

$\longrightarrow \quad$ Informations

Figure 5 Communication Process Option 2.

We should mention that this happened, while both places have an official spokesperson through a collective union.

These information processes are characteristic of a central power that appears afraid of losing control, while facing a non-united audience. Unfortunately, besides slowing down actions, it puts the FFDB in a difficult position, taken as the reference point to complain on others etc. Far from reuniting lace-makers, it even makes them more divergent.

\section{Clustering non-aligned partners}

The reader must have understood the rivalry still existing between various lace makers' in-between the Calais and Caudry places and within each place as well. We have already described the complexity in setting-up meetings. However, at some point, we needed to get everybody around the table to decide, among other points, upon the new collective brand identity. To settle the issue, we used a process that worked well and that we would recommend to other researchers facing a similar situation. First, we organized two separate meetings, one for each place. All lace-makers from each area were invited to attend. Some made the choice of not coming though (a minority). Each meeting started with the researcher's presentation of the brand audit. Prior written report had been submitted to each lace-maker, so that they could read the complete audit. This lasted around 90 minutes. This step anchored the following reflection into a scientific feedback, hence barely discussed. Then using a scheme gathering the various aspects of the brand identity (see previous part of this paper), we organized a 60minute workshop until consensus was reached. Then, we confronted both visions and built a new aggregated identity that would match both visions. The idea was to find middle-point and not to impose one view over the other one. As a last step, a new meeting was organized and the researcher's aggregated proposal presented. Each point was discussed and eventually updated. Consensus was reached. Acting as scientific authority, the researcher was several times asked to give his own vision. This was particularly the case for choice of the new brand name in Figure 6. 


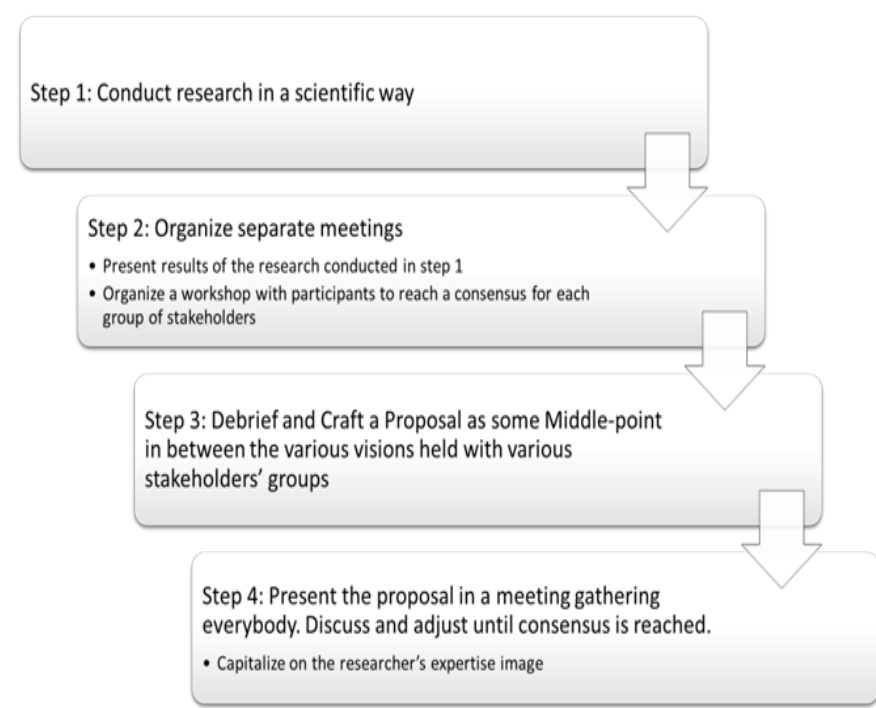

Figure 6 Decision-making enhancement in clustering "enemies".

\section{Collective ingredient strategic branding}

This research helped us identify more specifically the various factors that are at stake when such branding strategy is sought-after. Each of them has deadlines and business priorities that go before reflection on the collective brand. In addition, in most cases, the IP holder of the collective brand has no notion of branding or marketing. Therefore, a basic outcome of our research would be to recommend outsourcing of the collective-brand management. More specifically, we have the following factors: IP holder (here the FFDB), clients of the collective brand (Lace Makers only in the present case), users of the collective brand (manufacturers and retailers), and influencersif the strategy is then done properly-(final users). Therefore, if the strategy is to succeed, it needs full support of lace-makers, as proud ambassadors of the label. If no collective-play is on the agenda, better not capitalizing on the brand.

\section{Acknowledgements}

None.

\section{Conflict of interest}

Author declares there is no conflict of interest in publishing the article.

\section{References}

1. Wernerfelt B. A resource-based view of the firm. Strategic management J. 1984;5(2):171-180.

2. Leek S, Christodoulides G. A literature review and future agenda for $b 2 b$ branding: Challenges of branding in a b2b context. Industrial Marketing Management. 2011;40(6):830-837.

3. Rooney JA. Branding: A trend for today and tomorrow. J Product \& Brand Management. 1995;4(4):48-55.

4. Abbo MH. An exploratory study on the impact of two ingredient branding strategies on the host brand. In: Joseph Chapman, editor. Association of Marketing Theory and Practice. Ball State University, South Carolina, USA; 2006;4:191-199.

5. Norris DG. Ingredient branding: A strategy option with multiple beneficiaries. J Consumer Marketing. 1992;9(3):19-31.
6. Boad B. Co-branding comes of age. Managing Intellectual Property. 1999.

7. Bengtsson A, Servais P. Co-branding on industrial markets. Industrial Marketing Management. 2005;34:706-713.

8. Su J, Dyer CL, Gargeya VB. Strategic sourcing and supplier selection in the us textile-apparel-retail supply network. Clothing \& Textiles Research J. 2009;27(2):83-97.

9. McCarthy MS, Norris DG. Improving competitive position using branded ingredients. J Product \& Brand Management. 1999;8(4):267-285.

10. Desai KK, Keller KL. The effects of ingredient branding strategies on host brand extendibility. J Marketing. 2002;66(1):73-93.

11. Pfoertsch W, Luczak CA, Beuk F, et al. In-branding: Development of a conceptual model. Academy of Marketing Studies J. 2007;11(2):123-135.

12. Hines JD, O Neal GS. Underlying determinants of clothing quality: The consumers' perspective. Clothing \& Textiles Research J. 1995;13(4):227-233.

13. Veltz P. Places and links. Territorial policies in a globalizing world: Edouard of the Aube. 2002.

14. Porter ME. The competitive advantage of nations. New york: Harvard business school; 1990. p. 875.

15. Sabel CF, Piore MJ. The second industrial divide. The Johns Hopkins University Press, New York, USA; 1984;13(4):612-615.

16. Bouabdallah K, Tholoniat A. Competitiveness cluster and territorial economic intelligence: Contours and challenges of a new territorial industrial policy. 8th European forum Economic Intelligence. 2006.

17. Pecqueur B, Zimmerman JB. Economy of proximities. In: Lavoisier H, editor. Paris: Paris-Hermes Science Publications; 2004. p. 264.

18. Babcock BA, Hayes DJ, Lawrence JD, et al. Creating a geographically linked collective brand for high-quality beef: A case study. Iowa State University, USA; 2008. p. 1-232.

19. Babcock BA, Clemens R. Geographical indications and property rights: Protecting value-added agricultural products. Midwest Agribusiness Trade Research and Information Center. Iowa State University, USA; 2004. p. 1-51.

20. Clemens RL. Keeping farmers on the land: Adding value in agriculture in the veneto region of italy. Midwest Agribusiness Trade Research and Information Center. Iowa State University, USA; 2004. p. 1-27.

21. Hayes DJ. The iowa- 80 beef certification research project. Center for Agricultural and Rural Development and Iowa Beef Center. Iowa State University, USA; 2005

22. Keller KL. Strategic brand management-building, measuring, and managing brand equity. 4th ed. Global edition, UK; 2013. p. 1-591.

23. Scudeller A. Products under geographical indications. Advantages and disadvantages for producers. In: H Ilbert, Y Tekelioglu, editors. Local products, geographical indications and sustainable local development in the Mediterranean countries. CIHEAM, Montpellier, France; 2009. p. $67-71$.

24. Chamberlin E. Theory of monopolistic competition. American Economic Association. 1948;23(4):683-685.

25. Bradbury Huang H. What is good action research? Why the resurgent interest? Action Research. 2010;8(1):93-109.

26. Cherns AB. Models for the use of research. Human Relations. 1972;25(1):25-33.

27. Rapoport RN. Three dilemmas in action research: With special reference to the tavistock experience. Human Relations. 1970;23(6):499-514. 
28. Dick B. You want to do an action research thesis? How to conduct and report action research. Chapel Hill (Queensland): Interchange Publications. 1993. p. 90.

29. Jick TD. Mixing qualitative and quantitative methods: Triangulation in action. Administrative Science Quarterly. 1979;24(4):602-611.

30. Strauss A, Corbin J. Basics of qualitative research: Techniques and procedures for developing grounded theory. USA: SAGE Publications; 1998.
31. Fairclough N. Analysing discourse-textual analysis for social research. Routledge, UK; 2003. p. 272.

32. Dubois B, Paternault C. Observations: Understanding the world of international luxury brands: The dream formula. J Advertising Research. 1995;35(4):69. 